\title{
Effect of Enterococcus Faecalis Bacteria and Calcium Lactate on Concrete Properties and Self-Healing Capability
}

\author{
J.M. Irwan ${ }^{1, *}$, L.H. Anneza ${ }^{1}$, N. Othman ${ }^{2}$ \\ ${ }^{1}$ Jamilus Research Center for Sustainable Construction (JRC), Faculty of Civil and Environmental Engineering, \\ Universiti Tun Hussein Onn Malaysia (UTHM), Parit Raja, Batu Pahat, 86400, MALAYSIA \\ ${ }^{2}$ Micropollutant Research Centre (MPRC), Faculty of Civil and Environmental Engineering, \\ Universiti Tun Hussein Onn Malaysia (UTHM), Parit Raja, Batu Pahat, 86400, MALAYSIA \\ *Corresponding Author
}

DOI: https://doi.org/10.30880/ijscet.2019.10.01.008

Received 30 October 2018; Accepted 21 March 2019; Available online 01 June 2019

\begin{abstract}
Concrete is one of the most durable and long lasting product in construction industry. Durable, high strength, and crack resistant concrete does not happen by accident.Therefore, established guidelines and procedures should be followed to achieve the desired strength and concrete properties. Many attempts were explored by researchers in producing good quality of concrete with minimum cracks. One of the potential methods of crack healing is through bacteria incorporation in concrete. This study was done with the aim to determine the effect of concrete properties and self-healing capability of bacteria and calcium lactate in concrete. Strain of bacteria that was used in this study was locally isolated from fresh urine. The novelty of this study is that the enrichment process in the bacteria culture and method of calcium lactate added into concrete to accelerate bacteria growth process. Bacterium was isolated, enriched and identified using PCR and DNA sequencing. Mechanical properties tests such as compressive, flexural and tensile strength test were conducted. Self-healing capabilities of the concrete were tested using UPV and stereomicroscope. SEM and EDX were conducted to verify and confirm the bacteria precipitation of calcium carbonate. It was found that $2.18 \mathrm{~g} / \mathrm{L}$ of calcium lactate with $3 \%$ Enterococcus faecalis increase the compressive strength from $36 \mathrm{MPa}$ (Control) to $39.6 \mathrm{MPa}$. Flexural strength test achieved 6.72 MPa from 4.78 MPa. This increase in mechanical properties was possibly due to calcium carbonate formed due to the bacteria ability to precipitate calcium carbonate through urease enzyme. This was confirmed through SEM and EDX. Formation of calcium carbonate is directly responsible for self-healing capabilities that was analyzed through UPV and stereomicroscope. The increased of concrete properties and crack healing process proof that addition of specific bacteria strain resulted to a more durable concrete.
\end{abstract}

Keywords: Bacteria identification, mechanical properties, durability, morphology

\section{Introduction}

Bacteria strain added in concrete as one of alternative to improve concrete properties and self-healing from cracks and had been studied by many researchers from all over the world (Dick et al., 2006, Emilio et al., 2008 Abo-El-Enein et al., 2012, Amirreza et al., 2014, and Leena et al., 2014). Bacteria strains added in concrete that were used by researchers were isolated from various sources like soil, water, mud, springs and others and it were resulted to a 
positive impact. One of the criteria of the bacteria is its survival in high alkalinity and an environment with near to zero oxygen (Jonkers and Erik, 2008). This condition is resembles as condition of concrete environment.

Understanding the important to explore other sources of bacteria, this study was focused in isolating bacteria from fresh urine. Literature already proved that high content of urea in the urine will be a good source to isolate ureolytic bacteria to be added in the concrete. Precipitation of calcium carbonate by bacteria is highly due to the production of urease enzyme from ureolytic bacteria. The present of ureolytic bacteria with urease enzyme will accelerate calcium carbonate production and indirectly will occupy concrete pores or any pores at the cracking area. Reduction of pores and crack in the concrete will significantly improve concrete properties. However, methods in which bacteria are added into concrete and type of bacteria use are varies. Therefore there is a need to study the effect of bacteria and calcium lactate addition in the concrete environment.

\section{Experimental Program}

\subsection{Bacterium}

A bacterium that was used throughout the study is a strain isolated from fresh urine. After isolation, the bacteria strain is enriched to suit concrete environment by purging flask that containing the bacteria with nitrogen gas and increasing the $\mathrm{pH}$ level with sodium hydroxide $(\mathrm{NaOH})$. Survival of bacteria was monitored along this study. PCR and DNA sequencing was used to identify the bacteria strain. It is a popular technique to identify bacteria as it is not only fast but resulted toan accurate strain (Kit Boye et al., 1999 and BS EN 12390-3, 2009).

\subsection{Isolation and Enricment of Bacteria}

A process of enrichment as in (Fig. 1) was adopted in isolating the respected strain of bacteria. Isolation process involved a serial dilution streaking plate, strain purification and gram staining. All media used were autoclave at $121^{\circ} \mathrm{C}$ for 15 minutes to ensure sterilization. The composition of enrichment media for the bacteria is as follow:

i. Composition of control sample= Nutrient broth $(25 \mathrm{ml})+$ Urea $40 \%(10 \mathrm{ml})$

ii. Composition of bacteria sample $=$ Nutrient broth $(25 \mathrm{ml})+$ Urea $40 \%(10 \mathrm{ml})+$ Urine $(1 \mathrm{ml})$

The increase of $\mathrm{pH}$ during enrichment process is to ensure that the bacteria can survive in high alkaline condition in concrete. It is also attributes to high urease activity which leads to high carbonate precipitation rate. The $\mathrm{pH}$ of each sample was adjusted to an alkaline condition by adding sodium hydroxide until $\mathrm{pH}$ value reaches the range of 9-11.

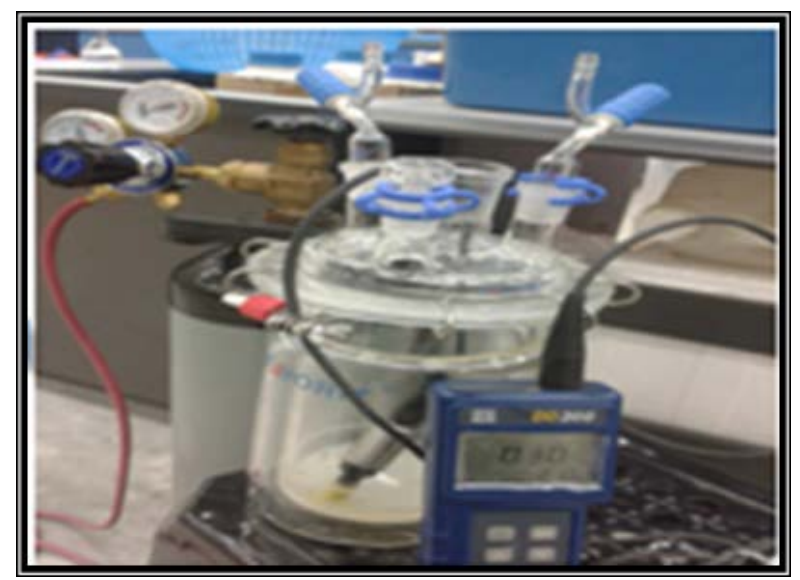

Fig. 1 - Enrichment flask containing bacteria

\subsection{DNA Qualification and PCR of Bacteria}

DNA quantification was quantified spectrophotometrically using a Nanodrop 2000 spectrophotometer (Fisher Scientific).

The polymerase chain reaction(PCR) condition was a 10X PCR Buffer, $25 \mathrm{~mm} \mathrm{MgCl}_{2}, 2.5 \mathrm{~mm}$ dNTPs, $10 \mu \mathrm{mol}$ each primer (27F; 1492R), 5U Taq DNA polymerase. Universal 16SrDNA PCR was performed with forward and reverse primers, which are 27 (forward primer) 5'-AGAGTTTGATCMTGGCTCAG-3' and 1492 (reverse primer) 5'- 
GGGTTACCTTGTTACGACTT-3’. After 35 cycles consisting of denaturation at $95^{\circ} \mathrm{C}$ (30 Seconds), Annealing at 50

${ }^{\circ} \mathrm{C}$ (30 Seconds) and extension at $72{ }^{\circ} \mathrm{C}$ (1 min and 30 seconds), the PCR product is analyzed on an agarose gel. A band indicating a fragment was shown by agarose gel electrophoresis. The results were blasted to National Centre for Biotechnology Information (NCBI) database.

\subsection{Preparation of Concrete Test Sample}

Concrete samples were prepared with Ordinary Portland Cement (OPC), fine aggregate (sand), coarse aggregate, water, bacteria liquid culture and calcium lactate solution. Table 1 shows the applied mixing proportions used in this study. This study was divided into two phases where the first phase is evaluating the bio-concrete compressive and flexural strength. The first phase uses concrete cube of $150 \mathrm{~mm} \times 150 \mathrm{~mm} \times 150 \mathrm{~mm}$ and prism of $500 \mathrm{~mm} \times 100 \mathrm{~mm}$ $\times 100 \mathrm{~mm}$. The second phase is evaluating the self-healing of the bio-concrete. This phase consists of prism embedded with 2R8 steel reinforcement and cube with steel plate of $150 \mathrm{~mm} \times 0.3 \mathrm{~mm} \times 20 \mathrm{~mm}$ used to create standardized crack. The verification of self-healing was conducted with Scanning Electron Microscope (SEM) and Energy Dispersive Spectroscope (EDX).

Table 1 - Mixing proportion of bio-concrete.

\begin{tabular}{lc}
\hline Materials & $\begin{array}{c}\text { Weightage } \\
\text { (kg) }\end{array}$ \\
\hline Cement & 63 \\
Fine aggregate (sand) & 111.6 \\
Coarse aggregate & 183 \\
Water (w/c 0.5) & 33.2 \\
Enterococcus faecalis & 1 \\
Calcium lactate & $0.22 \mathrm{~g} / \mathrm{L}$ \\
& $1.09 \mathrm{~g} / \mathrm{L}$ \\
& $2.18 \mathrm{~g} / \mathrm{L}$ \\
\hline
\end{tabular}

\subsection{Compressive and Flexural Strength}

Bio-concrete properties studies including compressive and flexural strength were the first phase of this study. Compressive strength test is conducted using a standardized cube. The test was conducted in triplicates as is accordance to BS EN 12390-3, (2009). Flexural strength test was conducted using standard prism size. The test is conducted based on BS EN 12390-5, (2009).

\subsection{Self-Healing of Bio-concrete}

Second phase of this study is to determine the bio-concrete self-healing capability. This is done with prism and cube. The reinforced prism is fabricated and after 28 days of dry curing, crack is created by 3-point bending. The cracks on all prism samples were created simultaneously by applying load on the prisms at the same time. This causes the prisms to crack but not break due to the reinforcement within the prism (Wang et al., 2012). Apart from that, cubes were fabricated and steel plate was used in fresh bio-concrete cubes. The steel plate was then removed after 24 hours. The cracks created on Prisms and cubes were analyzed on the 20, 40, 70 and 100 days using Stereomicroscope and Ultrasonic Pulse Velocity (UPV) (Wiktor and Jonkers, 2011, Wang et al., 2012, Tittelboom et al., 2012, Quiviger et al., 2012, Varenyam et al., 2013, Wiktor et al., 2013, Guadalupe et al., 2014and Zhong and Yao, 2018). Preparation of both prism and cubes for self-healing is as in Fig. 2. 


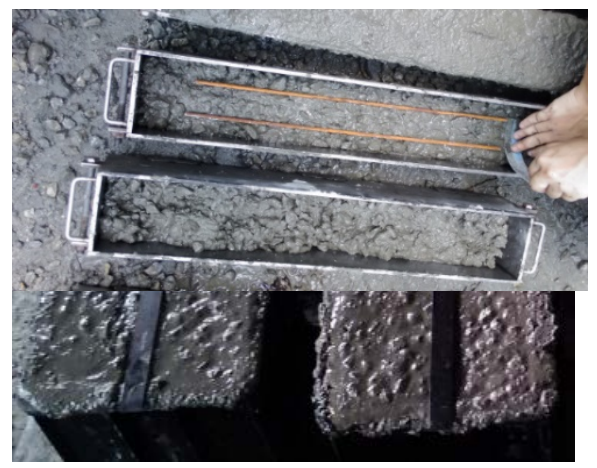

Fig. 2 - Prism and cubes for phase 2

\subsection{Verification of Bio-concrete Morphology through SEM and EDX}

Scanning Electron Microscope (SEM) and Energy Dispersive Spectroscopy (EDX) are used to observe and analyze bio-concrete morphology. Small portions were cut from $150 \mathrm{~mm} \times 150 \mathrm{~mm} \times 150 \mathrm{~mm}$ cube to perform SEM and EDX. Method to prepare samples for SEM and EDX was similar as Faiz et al.,(2014). Both SEM and EDX were conducted based on DD ISO/TS 10798, (2011).

\section{Experimental Results and Discussions}

\subsection{Bacteria Identification}

Bacteria identification was conducted through DNA extraction, PCR and analyzing through BLAST software. The absorbance measurement that was taken to calculate DNA purity was at $260 \mathrm{~nm}$ and $280 \mathrm{~nm}$. DNA samples were considered free from protein contamination if the $A_{260}$ to $A_{280}$ ratio was between 1.8 and 2.0. Table 2 presents results of protein ration as compare to control experiment.

Table 2 - Quantification result

\begin{tabular}{lccccc}
\hline No. & $\begin{array}{c}\text { Sample } \\
\text { ID }\end{array}$ & $\begin{array}{c}\text { Nucleic } \\
\text { Acid } \\
\text { Conc. }\end{array}$ & Unit & $\mathbf{2 6 0 / 2 8 0}$ & $\mathbf{2 6 0 / 2 3 0}$ \\
\hline 1 & $\mathrm{U}$ & 159.7 & $\mathrm{ng} / \mu \mathrm{l}$ & 1.84 & 2.12 \\
\hline
\end{tabular}

A PCR product of about $600 \mathrm{~kb}$ in size was successfully amplified from the sample. The process and timing for each cycle are as in Table 3 and the agarose gel product is shown Fig. 3.

Table 3 - PCR parameter

\begin{tabular}{lccc}
\hline Stage & $\begin{array}{c}\text { Temp. } \\
\left({ }^{\mathbf{0}} \mathbf{C}\right)\end{array}$ & $\begin{array}{c}\text { Time } \\
(\mathbf{m i n})\end{array}$ & $\begin{array}{c}\text { No. of } \\
\text { cycles }\end{array}$ \\
\hline $\begin{array}{l}\text { Initial } \\
\text { denaturation }\end{array}$ & 95 & $5: 00$ & 1 \\
$\begin{array}{l}\text { Denaturation } \\
\text { Annealing }\end{array}$ & 95 & $0: 30$ & 35 \\
Extension & 72 & $1: 30$ & 35 \\
Final & 72 & $7: 00$ & 1 \\
extension & & & \\
End & 4 & - & - \\
\hline
\end{tabular}




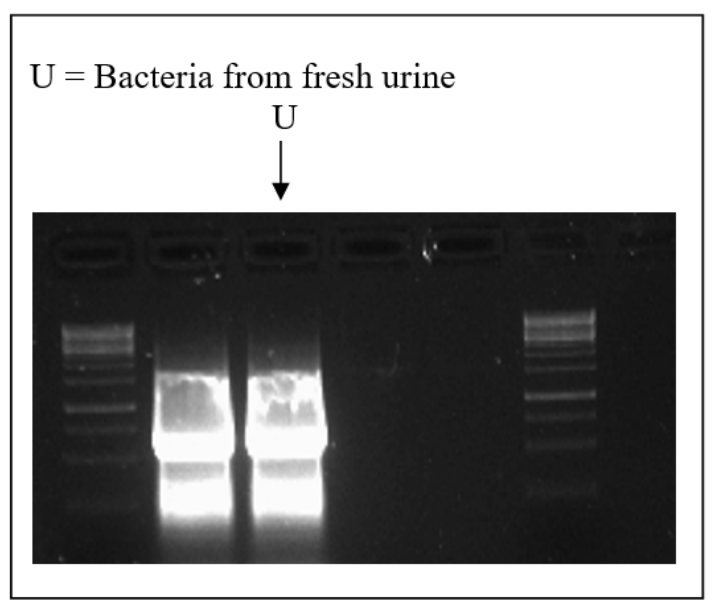

Fig. 3 - Agarose gel

After performing PCR reaction and getting the PCR product. A purification step is done using the Qiagen PCR Purification Kit. Identification of the isolate was performed and the DNA of isolated strain will be identified. The basic unit of DNA structure comprise of nucleotide, phosphate, deoxyribose sugar and a nitrogen base. Each deoxyribose sugar bonds convalently in a repeating pattern with two phosphates, One of the bond is to 5' (five primer) another bond is to 3' carbon on deoxyribose. This specifies the order and direction of each strand. The nitrogen bases, purines and pyrimidines attach by covalent bonds at the 1' position of the sugar. Pairing of purines and pyrimidines is dictated by the formation of hydrogen bonds. Thus DNA sequence, is the pairing of purine Adenine (A) pairs with pyrimidine Thymine (T) and the purine Guanine (G) pairs with pyrimidine Cytosine (C) (Talaro and Chess, 2012). The DNA sequence is then compared to similar or to any other DNA sequences by uploading the sequence to BLAST programs. BLAST is a program that is supported by the National Center for Biotechnology Information (NCBI). The result of BLAST software is shown as a phylogenetic tree as shown in Fig. 4.

\subsection{Compressive and Flexural Strength}

Effect of Enterococcus faecalis with calcium lactate on compressive strength at the age of 7,14 and $28^{\text {th }}$ day was studied and it was found that inclusion of Enterococcus faecalis in concrete significantly increases the compressive strength. Results of compressive strength by using Enterococcus faecalis with different concentrations of calcium lactate are presented in Fig. 5. The highest increment of strength is 39.6 MPa which was achieved with addition of 2.18 $\mathrm{g} / \mathrm{L}$ calcium lactate. The increment of strength by $0.22 \mathrm{~g} / \mathrm{L}$ is $37.8 \mathrm{MPa}$ which is an increase of $2.2 \%$ from bio-concrete (E.faecalis). Whereas, addition of $1.09 \mathrm{~g} / \mathrm{L}$ achieved strength of $38.5 \mathrm{MPa}$. Thus, increasing strength by $4.1 \%$. Lastly, the addition of $2.18 \mathrm{~g} / \mathrm{L}$ has allowed concrete to increased in strength by 7\%, which is $39.6 \mathrm{MPa}$. While compared to control, the increments are 5\%,6.9\% and $10 \%$ with $0.22 \mathrm{~g} / \mathrm{L}, 1.09 \mathrm{~g} / \mathrm{L}$ and $2.18 \mathrm{~g} / \mathrm{L}$ respectively. Addition of calcium lactate has provided additional calcium ions to increase the amount of precipitated calcium carbonate. Hence, higher compressive strength is achieved. Trend of results obtained from this research are similar to Ramachandran et al., (2005) which both studies resulted to an improvement of compressive strength with the addition bacteria in concrete. Where, a $15.4 \%$ increment of strength was reported. Comparatively to this study, the difference in increment of strength is by $8.4 \%$. This is due to the difference in bacteria used. As different bacteria produce calcium carbonate in different pace. The shewanella species was reported to be aided increment of compressive strength in mortar of up to 25\% after 28 days (Ramachandran et al., 2001).

Apart from that, flexural strength test have similar results as compressive strength test. Flexural strength of concrete increased with the addition of Enterococcus faecalis and calcium lactate. Flexural strength was conducted at the age of 28 days. Fig. 6 shows the results of Flexural strength test. Addition of $0.22 \mathrm{~g} / \mathrm{L}$ calcium lactate achieved an increment of flexural strength by $14.2 \%$ compared to Enterococcus faecalis. The highest increment of flexural strength is by using $2.18 \mathrm{~g} / \mathrm{L}$ calcium lactate which increased strength by $31.25 \%$ compared to Enterococcus faecalis. This is followed by $1.09 \mathrm{~g} / \mathrm{L}$ which increased the strength by $29.49 \%$. Increment of flexural strength compared to control are 22.38\%, 38.70\% and 40.59\% with $0.22 \mathrm{~g} / \mathrm{L}, 1.09 \mathrm{~g} / \mathrm{L}$ and $2.18 \mathrm{~g} / \mathrm{L}$ respectively. Overall, increased of flexural strength with the addition of calcium lactate is higher compared to bio-concrete.Similar trends of improvement of flexural strength with addition of bacteria in concrete were reported by previous studies (Chattopadhyay et al., 2011, Majumdar et al., 2012 and Parmar et al., 2013). Previous study proved that the use of bioremediase in mortar beam have recorded to an increase of 33\% with $3 \mu \mathrm{g} / \mathrm{g}$ bioremediase compared to control (Majumdar et al., 2012).An addition of calcium lactate acts as a food source for the bacteria to further increased the precipitation therefore increasing the strength of concrete properties. This is verified with SEM and EDX. 


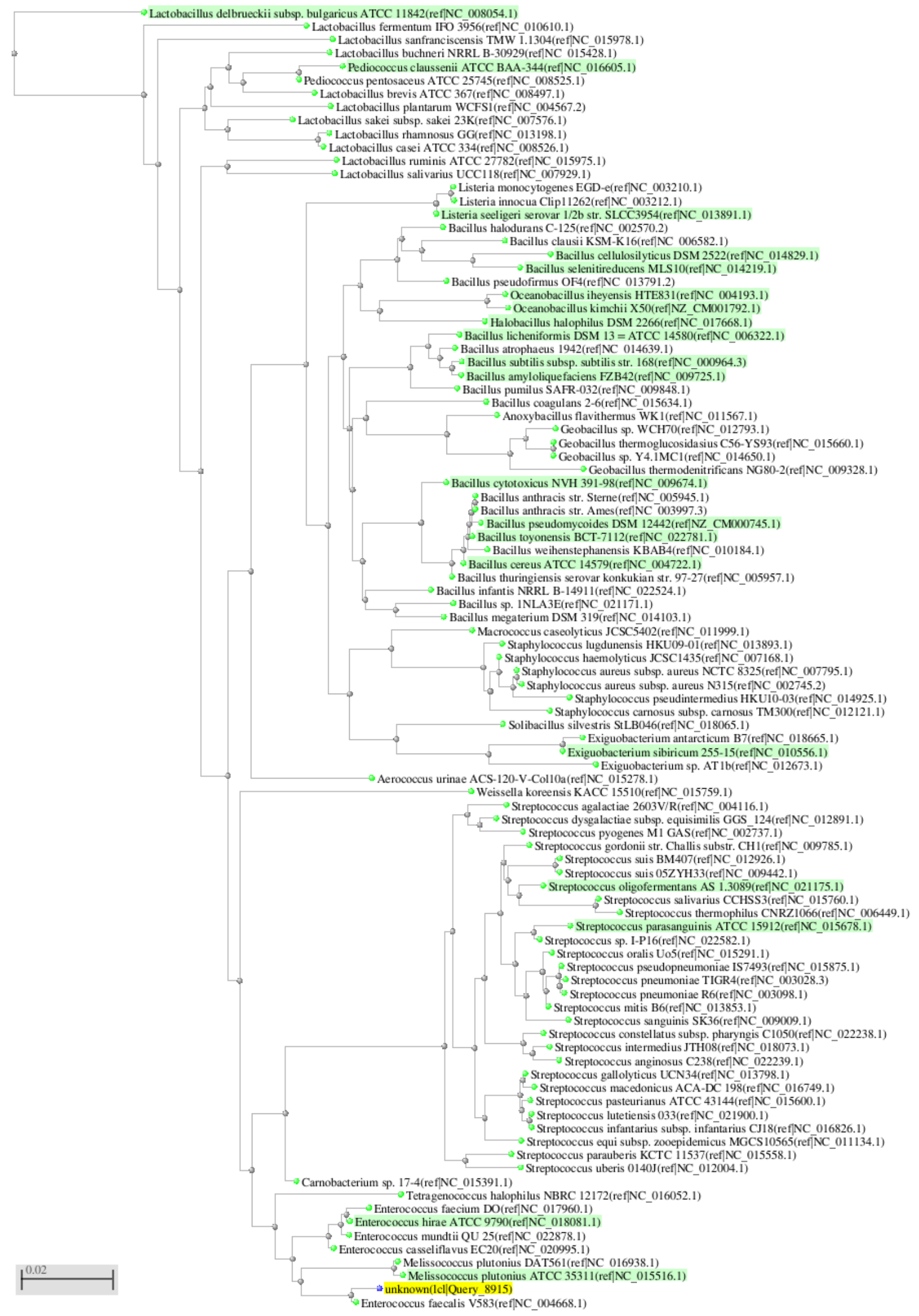

Fig. 4 - Phylogenetic tree of enterococcus faecalis 


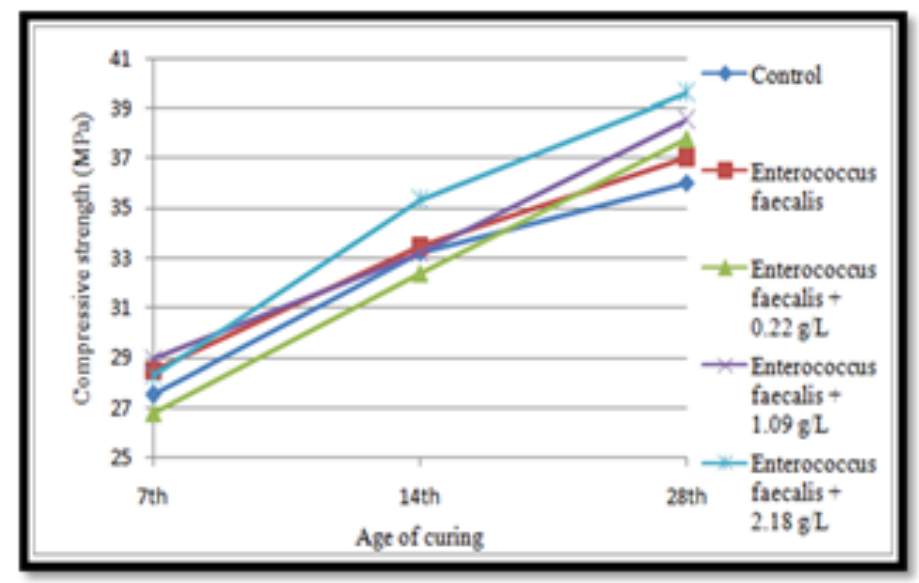

Fig. 5 - Compressive Strength of bio-concrete and calcium lactate

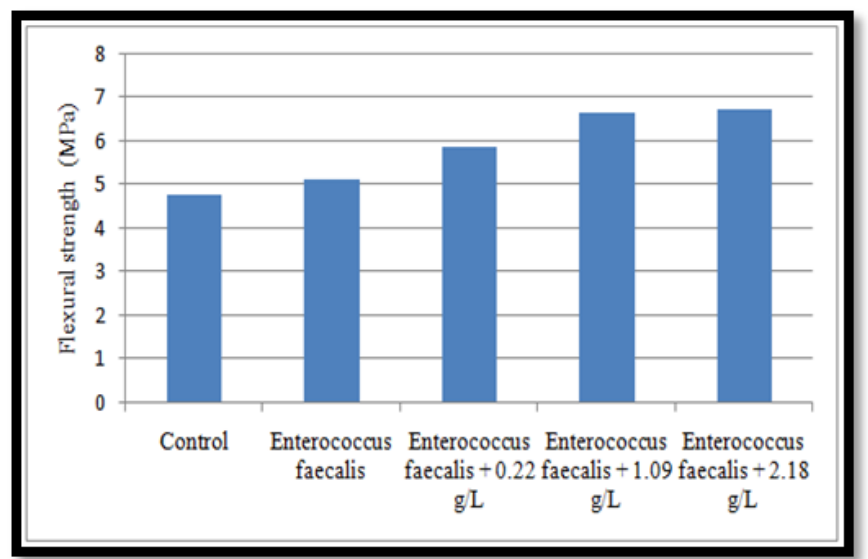

Fig. 6 - Results of flexural strength test for specimens containing bacteria and calcium lactate

\subsection{Self-Healing of Bacteria}

Second phase of this study involved self-healing of bio-concrete with added calcium lactate. Ultrasonic Pulse Velocity (UPV) and Stereomicroscope were used to verify self-healing and data is collected after crack is formed at the age of 20, 40, 70 and 100 days. The self-healing is divided to crack with metal plate and crack with three-point bending. Fig. 7 shows the crack with metal plate results for UPV and Fig. 8 shows the crack with three point bending results for UPV.

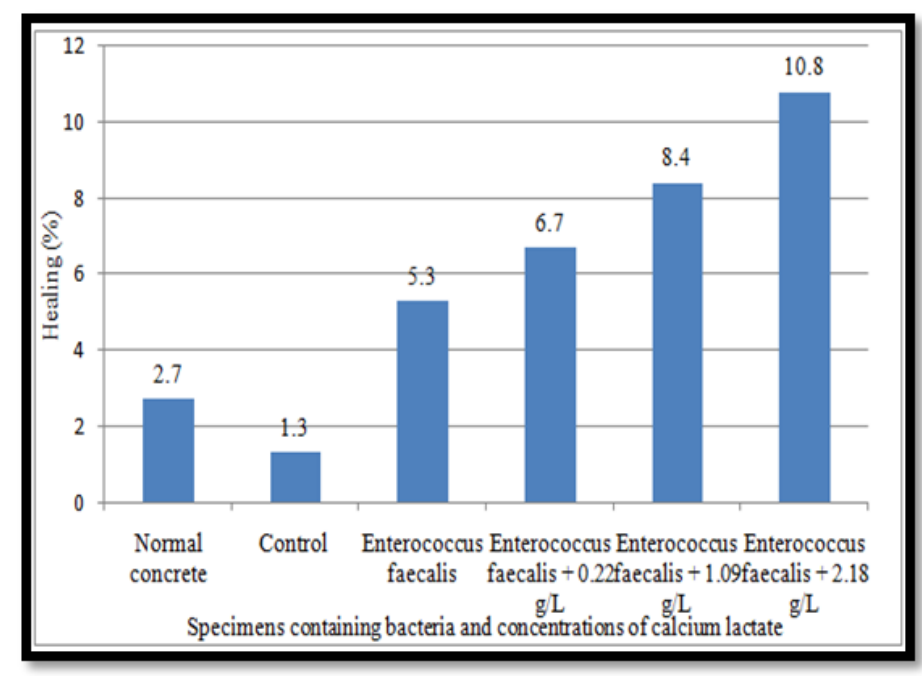

Fig. 7 - Percentage of healing of bacteria and calcium lactate in concrete by UPV 


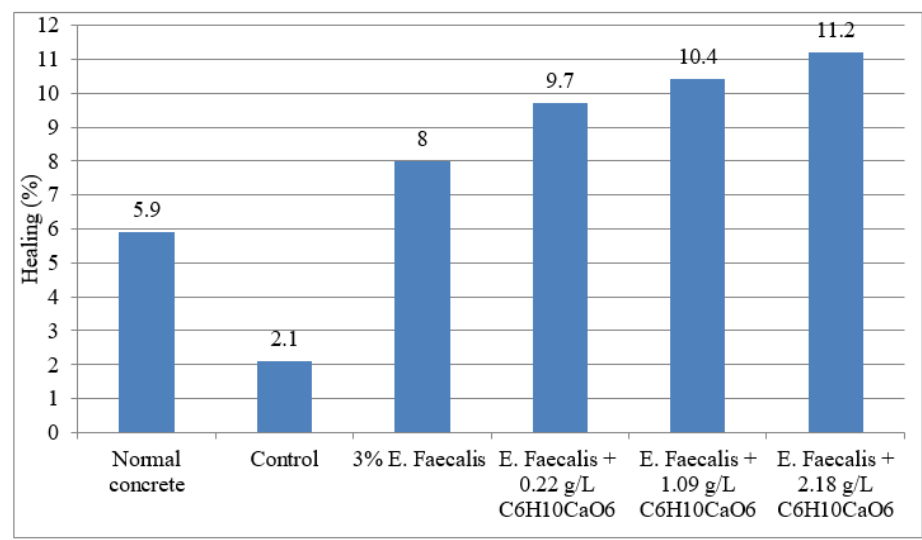

Fig. 8 - Percentage of healing for crack by 3-point bending

Percentage of healing obtained in this study are $2.7 \%, 1.3 \%, 5.3 \%, 6.7 \%, 8.4 \%$ and $10.8 \%$ for normal concrete (without crack), control (with crack), 3\% E. Faecalis, E. Faecalis with 0.22 g/L, 1.09 g/L, $2.18 \mathrm{~g} / \mathrm{L}$ respectively. The highest increment of percentage is by $2.18 \mathrm{~g} / \mathrm{L}$ of calcium lactate which is $9.5 \%$ higher than the control (with crack) and $8.1 \%$ higher than normal concrete (without crack).On the other hand, the lowest increment is from concrete with $E$. Faecalis, which improved healing by $4 \%$ compared to control (with crack) and $2.6 \%$ compared with normal concrete (without crack).

Self-healing observation through stereomicroscope was conducted with prism (three-point bending). The results were taken on the 20, 40, 70 and 100 days after crack is created. Results showan increasing trend in percentage of healing with bio-concrete containing calcium lactate. Fig 8 shows increment trend with addition of $0.22 \mathrm{~g} / \mathrm{L}, 1.09 \mathrm{~g} / \mathrm{L}$ and $2.18 \mathrm{~g} / \mathrm{L}$ of calcium lactate in bio-concretewhich improved healing of concrete by $9.7 \%, 10.4 \%$ and $11.2 \%$ respectively. The highest difference in increment is with concrete sample containing bacteria and $2.18 \mathrm{~g} / \mathrm{L}$ calcium lactate of up to $9.1 \%$ compared to control and $5.3 \%$ compared to normal concrete. This improvement of healing by calcium lactate addition has proven that bacteria utilize additional calcium added into bio-concrete. Result from compressive and flexural strength in concrete properties obtained in this study has shown similar trends which indicates that the addition of calcium lactate in concrete has positive results on the mechanical and healing capabilities of concrete.

Stereomicroscope data collected for bio-concrete containing Enterococcus faecaliswith different addition of calcium lactate is presented in Table 4 . An increase in self-healing percentage by $22.9 \%, 25 \%$ and $30.9 \%$ for bioconcrete containing $0.22 \mathrm{~g} / \mathrm{L}, 1.09 \mathrm{~g} / \mathrm{L}$ and $2.18 \mathrm{~g} / \mathrm{L}$ of calcium lactate respectively. The data obtained proved that the highest percentage of healing and difference compared to control is by adding $2.18 \mathrm{~g} / \mathrm{L}$ of calcium lactate. Bacteria in the concrete uses calcium lactate added in producing calcium carbonate. Calcium carbonate produced fills in the voids and resulted to strengthen the concrete. Results from this study arein line with study by Jonker and Erik, (2008).

Table 4 - Stereomicroscope results for prism

\begin{tabular}{|c|c|c|c|c|c|}
\hline \multirow{2}{*}{ Batch } & \multicolumn{4}{|c|}{ Days } & \multirow{2}{*}{$\begin{array}{c}\text { Percentage of } \\
\text { healing } \\
\text { (\%) }\end{array}$} \\
\hline & $\begin{array}{c}20 \\
(\mathrm{~mm})\end{array}$ & $\begin{array}{c}40 \\
(\mathrm{~mm})\end{array}$ & $\begin{array}{c}70 \\
(\mathrm{~mm})\end{array}$ & $\begin{array}{l}100 \\
(\mathrm{~mm})\end{array}$ & \\
\hline Control & 0.045 & 0.041 & 0.041 & 0.038 & 15.6 \\
\hline $\begin{array}{l}\text { Enterococcus } \\
\text { faecalis } 3 \%\end{array}$ & 0.029 & 0.024 & 0.023 & 0.023 & 20.7 \\
\hline $\begin{array}{l}\text { Enterococcus } \\
\text { faecalis }+0.22 \mathrm{~g} / \mathrm{L}\end{array}$ & 0.035 & 0.031 & 0.030 & 0.027 & 22.9 \\
\hline $\begin{array}{l}\text { Enterococcus } \\
\text { faecalis + } 1.09 \mathrm{~g} / \mathrm{L}\end{array}$ & 0.040 & 0.036 & 0.036 & 0.035 & 25.0 \\
\hline $\begin{array}{l}\text { Enterococcus } \\
\text { faecalis + } 2.18 \mathrm{~g} / \mathrm{L}\end{array}$ & 0.042 & 0.034 & 0.030 & 0.029 & 30.9 \\
\hline
\end{tabular}




\subsection{Verification through SEM and EDX}

Morphology tests such as Scanning Electron Microscope (SEM) and Electron Diffractive X-ray (EDX) are conducted as verifications. Small samples are prepared to conduct SEM and EDX. Both of which were conducted after samples reach maturity of 28 days. Fig. 9-14 shows the SEM results for this study.

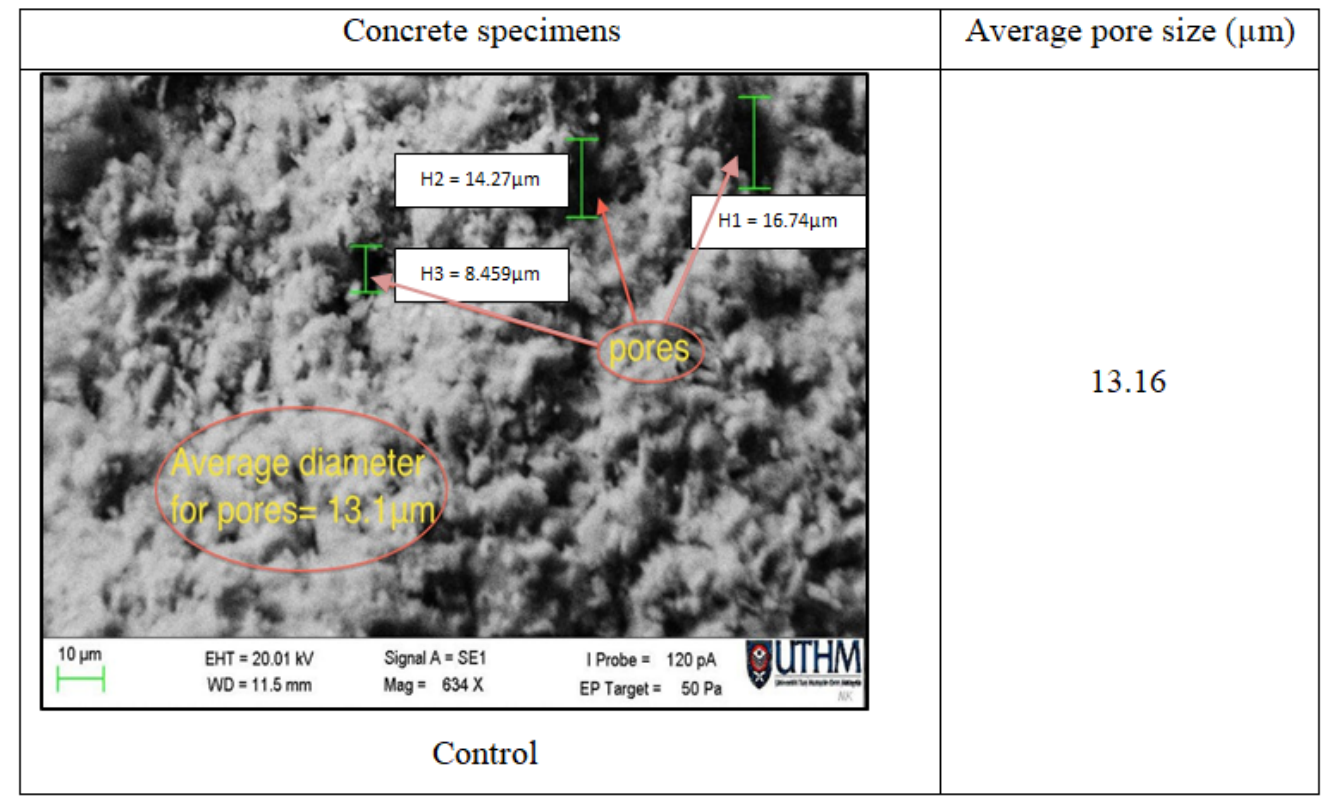

Fig. 9 - Microstructure of normal concrete

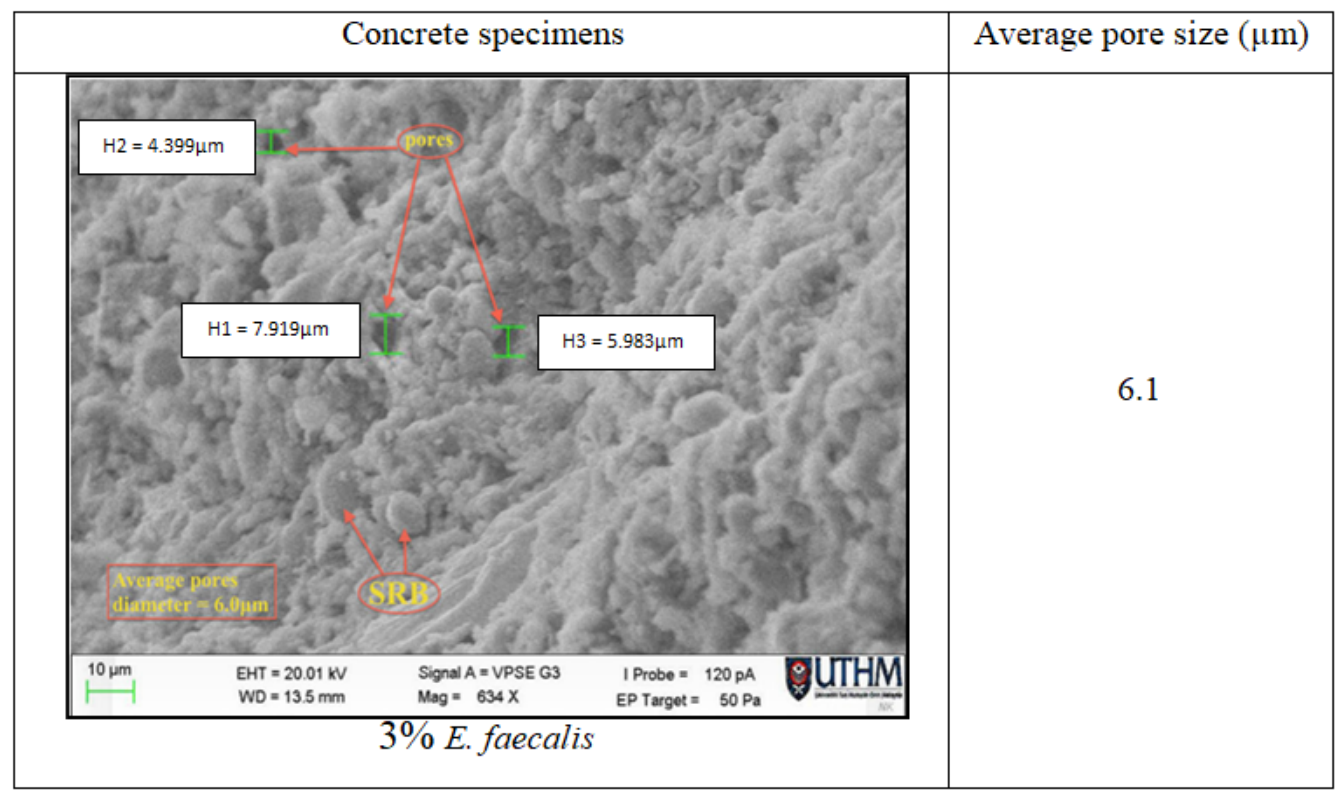

Fig. 10 - Concrete sample with $E$. faecalis 


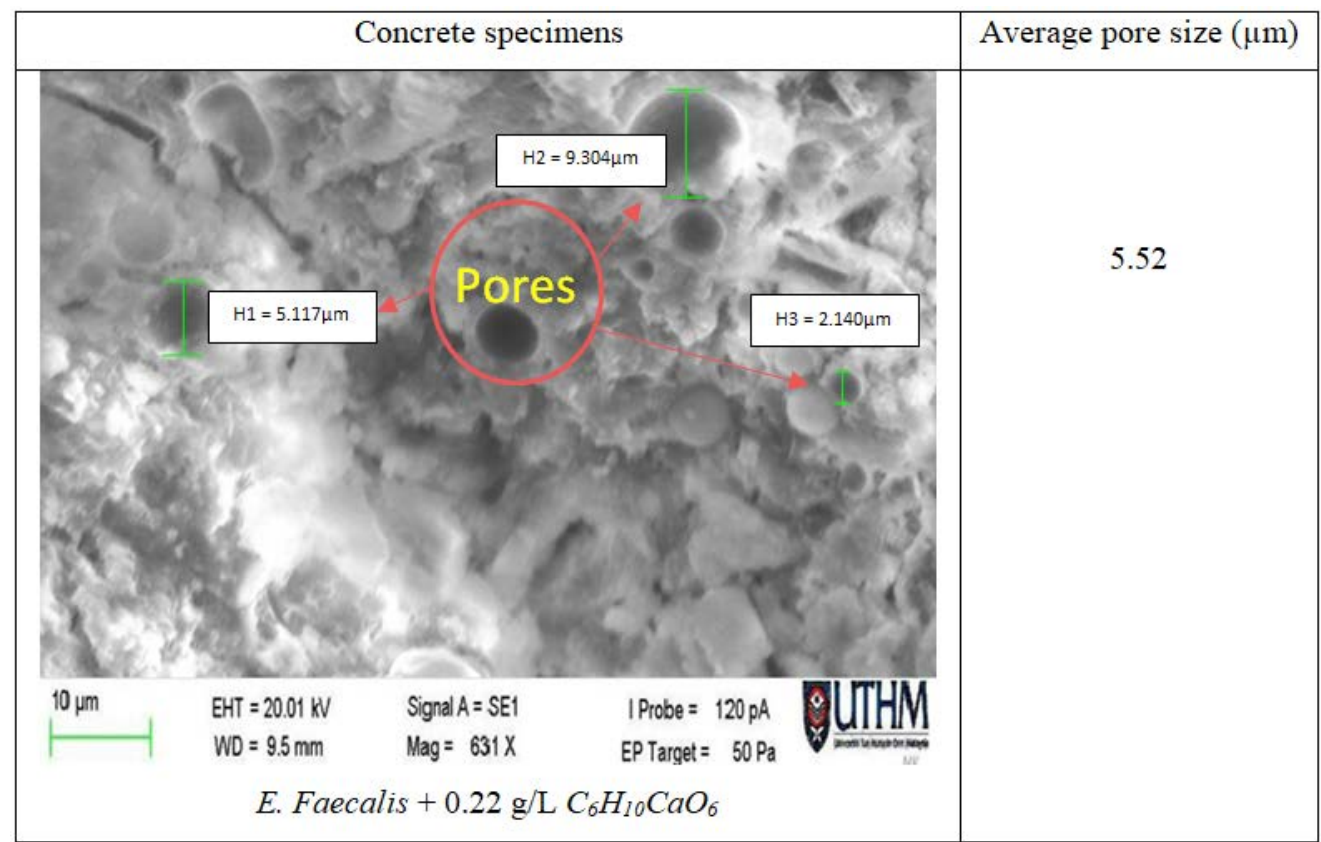

Fig. 11 - Sample with E. Faecalis and $0.22 \mathrm{~g} / \mathrm{L}$ calcium lactate

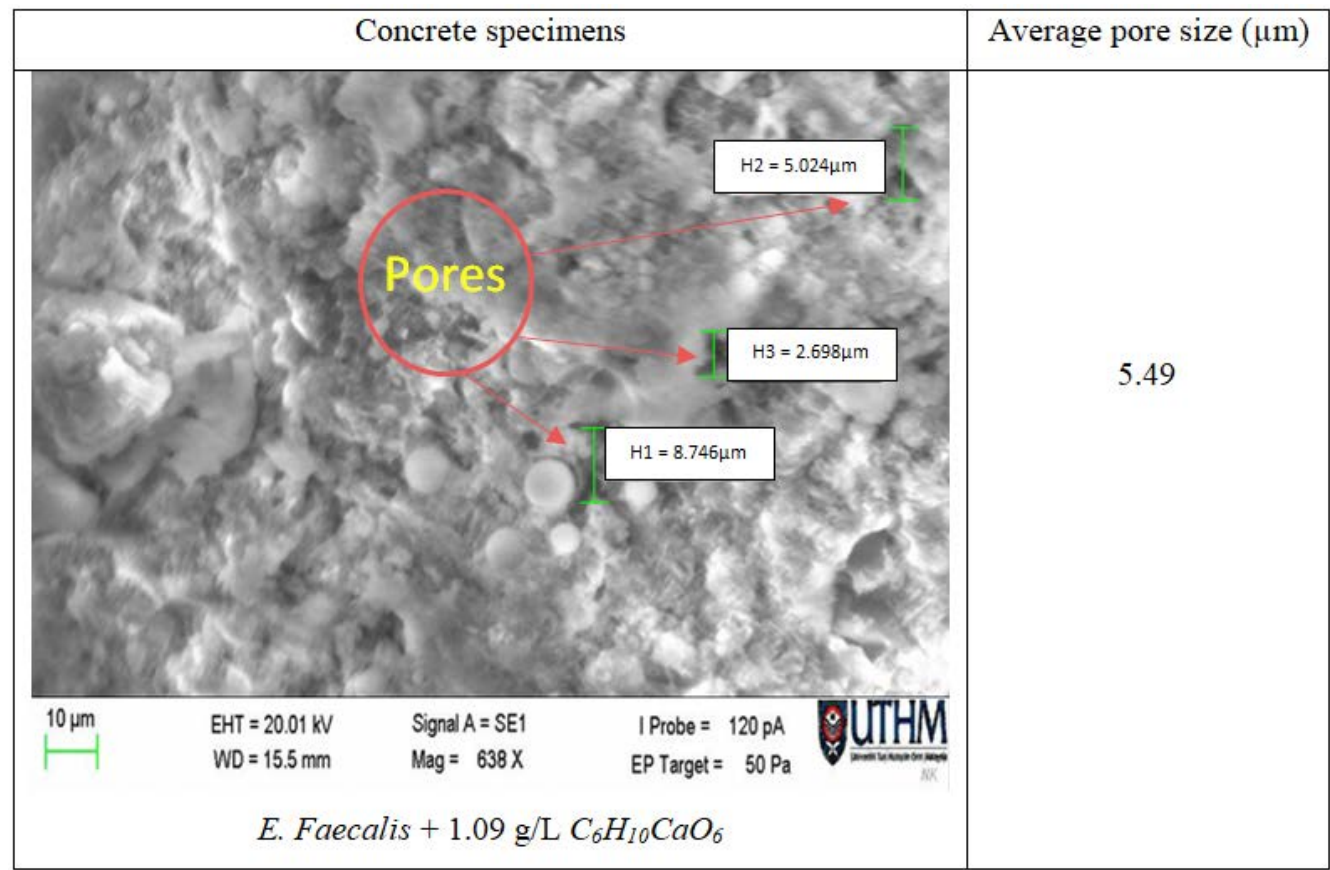

Fig. 12 - Concrete sample with E. Faecalis and 1.09g/L calcium lactate 


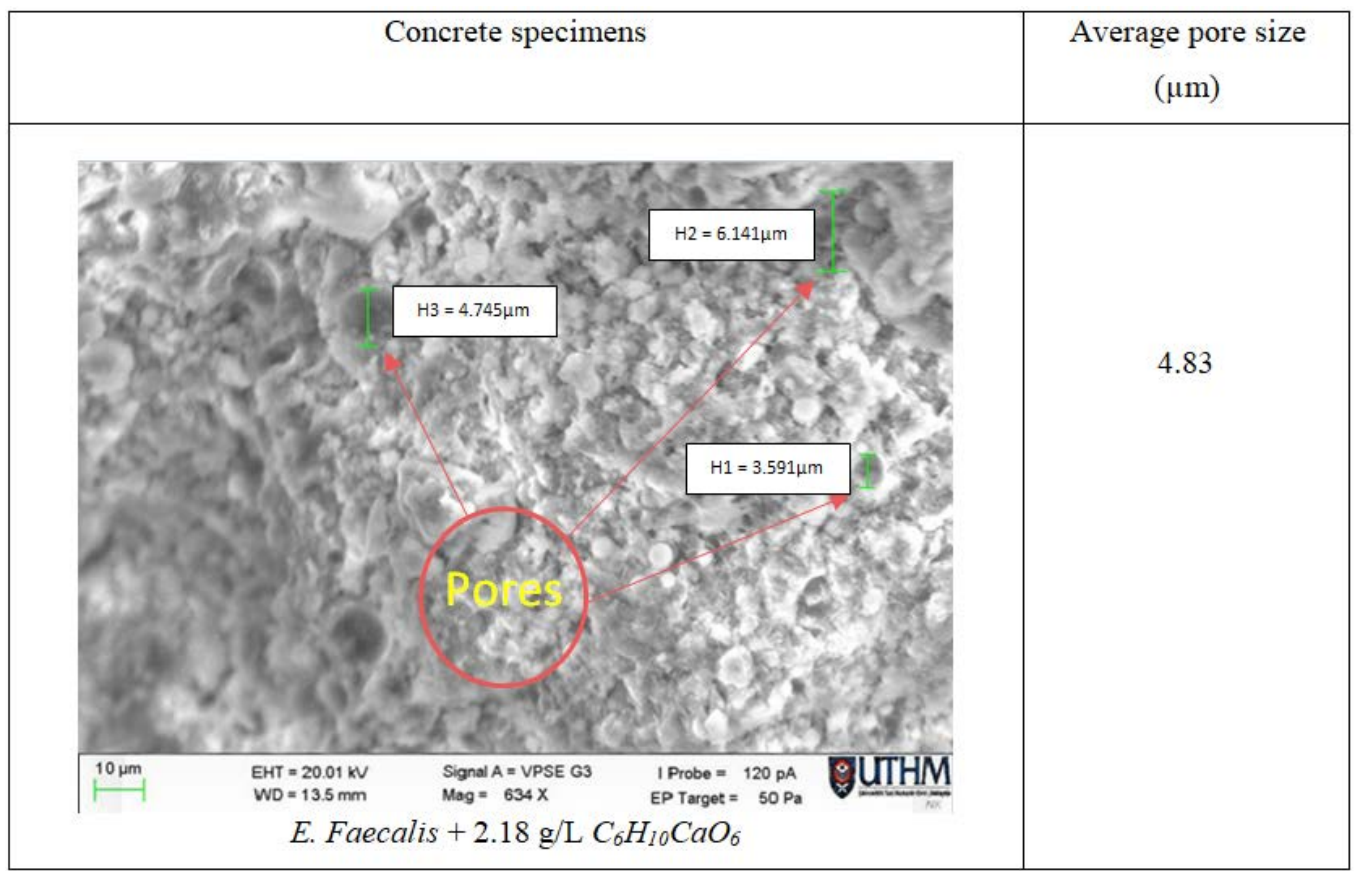

Fig. 13 - Microstructure of $E$. Faecalis and $2.18 \mathrm{~g} / \mathrm{L}$ calcium lactate

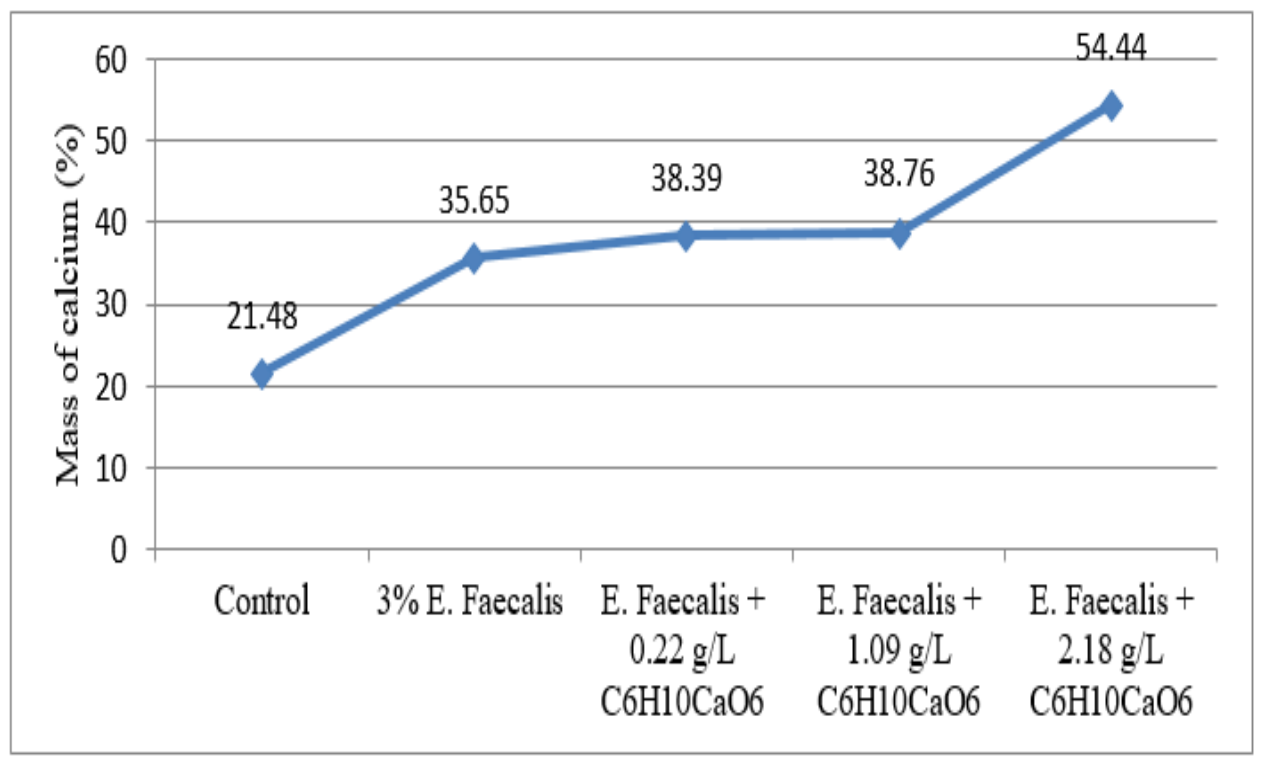

Fig. 14 - Comparison of calcium mass in control and E. Faecalis sample with calcium lactate

Concentrations of calcium lactate was added into concrete with 3\% Enterococcus faecalis and the microstructure of these concrete are analyze using SEM. The pore size difference between specimens with bacteria added in concentration of $0.22 \mathrm{~g} / \mathrm{L}, 1.09 \mathrm{~g} / \mathrm{L}$ and $2.18 \mathrm{~g} / \mathrm{L}$ compare to control are $58.05 \%, 58.28 \%$ and $63.29 \%$ respectively. The pores filled the concrete which improves concrete mechanical properties. Filling or concrete pores resulted to increase compressive and flexural strength. The results also have shown that addition of calcium lactate in bio-concrete improve concrete properties. Enterococcus faecalis produces urease enzyme which catalyzes hydrolysis of urea to $\mathrm{CO}_{2}$ and ammonia and finally resulting in an increase of $\mathrm{pH}$ and carbonate concentration in the bacterial environment (Dick et al., 2006, Chahal et al., 2010, Aiko et al., 2011, Wang et al., 2012 and Tittelboom et al., 2012). The production of calcium carbonate is facilitated with the addition of calcium ions in the form of calcium lactate through the bacteria enzymatic pathway (Chahal et al., 2010).

Fig. 14 shows the result of EDX for bio-concrete specimens containing calcium lactate of $0.22 \mathrm{~g} / \mathrm{L}, 1.09 \mathrm{~g} / \mathrm{L}$ and $2.18 \mathrm{~g} / \mathrm{L}$ respectively. Addition of calcium lactate with concentration of $0.22 \mathrm{~g} / \mathrm{L}, 1.09 \mathrm{~g} / \mathrm{L}$ and $2.18 \mathrm{~g} / \mathrm{L}$ resulted to 
an increase of calcium ion with38.39\%, 38.76\% and 54.44\% respectively. An increase of calcium mass signifies the precipitation of calcium carbonate by bacteria.

\subsection{Discussions}

Enterococcus faecalis from genus bacillus was successfully isolated from urine source. Results of the compressive and flexural strengths showed that with the addition of bacteria, the concrete has achieved higher strengths. While, adding calcium lactate has further improved the concrete properties. This is due to the calcite deposition by the bacteria in concrete, which reduces the concrete pores thus increasing the strengths. This is proven with SEM and EDX. The calcium lactate added acts as a food source for the bacteria. Enterococcus faecalis bacteria withureolytic enzyme had ability to hydrolysis of urea to $\mathrm{CO}_{2}$ and ammonia (Chahal et al., 2010). This study also results to an increase of pH and concentration of carbonate in the bacterial environment. An increment of $\mathrm{pH}$ is vital for survival of the bacteria as concrete is naturally high in alkaline. Based on Mayur and Jayeshkumar, (2013), there are two pathways for precipitation of calcium carbonate by bacteria. The first pathway usually involves sulphur cycle and particular sulphate reduction. This pathway is usually carried out by sulphate reducing bacteria under anoxic condition. Second pathway involves nitrogen cycle which is usually carried out by ureolytic bacteria. In this study, the addition of calcium lactate benefits the nitrogen pathway as calcium ions are taken in to combine with carbonate and resulted to calcium carbonate. Self-healing of concrete is analyzed through UPV and Stereomicroscope. Cracks were formed in concrete through using metal strip and applying 3-point bending and were studied throughout 100 days after formation of crack. Results showed that, addition of calcium lactate in concrete containing Enterococcus faecalis has significant improvement in healing. This increased in healing is due to microbial activity between the calcium lactate and bacteria which increased the precipitation of calcium carbonate or is known as calcite deposition in healing of concrete micro-cracks.

\subsection{Conclusions}

This study concluded that the metabolic processes of calcium carbonate production by bacteria can be influenced by adequate amount of calcium lactate. This study also shows that addition of calcium lactate in bio-concrete has profound effects on the concrete properties and self-healing. Different amount of calcium lactate added influence the production of calcium carbonate in the concrete.

\section{Acknowledgement}

The authors would like to thank the Faculty of Civil and Environmental Engineering, Universiti Tun Hussein Onn Malaysia and The Ministry of Education Malaysia for the Fundamental Research Grant Scheme (FRGS) Vot 1211.

\section{References}

Abo-El-Enein. S. A, Ali, A. H., Fatma, N.T. and Abdel-Gawwad, H. A. (2012). Utilization of microbial induced calcite precipitation for sand consolidation and mortar crack remediation. Housing and Building National Research Center, 8, pp.185-192.

Aiko, M., Katia, K., Kaminishikawahara, V., Moacyr, J., Henrique. K. and Marcos, M. F. (2011). Sand bioconsolidation through the precipitation of calcium carbonate by two ureolytic bacteria. Materials Letters. 65, pp 1730-1733.

Amirreza, T., Ali, K., Arezo, S., Ramin, A., Majid, M. Z. A., Fulazzaky, M. A., Rosli, M. Z.Chew, T. L., Warid, M. H., Norhaliza, H., Fatimah, N. M., Haidar, H. I. (2014). A review of self healing concrete research development. Journal of Environmental Treatment Techniques, Vol 2, Issue 1, pp. 1-11.

British Standard Institution. Part 3: Compressive strength of test specimens, London, BS EN 12390-3:2009.

British Standard Institution. Testing hardened concrete part 5: Flexural strength of test specimens.BS EN 123905:2009.

British Standard Institution. Nanotechnologies-Characterization of single wall carbon nanotubes using scanning electron microscopy and energy dispersive X-ray spectrometry analysis.DD ISO/TS 10798:2011.

Chahal, N., Siddique, R. and Rajor, A. (2013). Influence ofthe Bacteria on The Compressive Strength, Water Absorption and Rapid Chloride Permeability Of Concrete Incoporating Silica Fume. Construction and Building Materials, 37, pp. 645-651.

Chattopadhyay, B. D., Majumdar, S. Sarkar, M. and Chowdhury, T. (2011). The microbial protein bioremediase-A Prospective agent in construction technology. Jadavpur University, Kolkata, India. 
Dick, Jan., Windt, W. D., Bernard, D. G., Saveyn, H., Paul, V. D. M., De Belie, N., and Verstraste. W. (2006). Biodeposition of a calcium carbonate layer in degraded limestone by Bacillus species. Biodegradation, Springer, 17, pp.357-367.

Emilio, B. A., Mauricio S. S., Alaa C. and Moema, R. S. (2008). Coupled reliability model of biodeterioration, chlorde ingress and cracking for reinforced concrete structures. Structural Safety, 30, pp 110-129.

Faiz, U.A., Shaikh. and Steve, W. M. S. (2014). Mechanical and durability properties of high volume fly ash (HVFA) concrete containing calcium carbonate $\left(\mathrm{CaCO}_{3}\right)$ nanoparticles. Construction and Building Materials, 70, pp. $309-321$.

Guadalupe, S.B., Jonkers, H. M. and Shlangen, E. (2014). Characterization of Suitable Bio-Based Mortar For Concrete Repair. Construction and Building Materials, 67, pp. 344-352.

Jonkers, H. M. and Erik, Schlangen. (2008). Development of a bacteria-based self healing concrete. Tailor Made Concrete Structures, Edition.8. London: Taylor and Francis Group. pp 425-430.

Kit Boye, EstridHogdall and Martin Borre. (1999). Identification of bacteria using two degenerate 16S rDNA sequencing primers. Microbial Res. 154, pp. 23-26.

Leena, C., Rajesh, K. V. and Vishakha, B. (2014). Microbial Carbonate Precipitation by Urease Producing Bacteria in Cementitious Materials. International Journal of Advanced Biotechnology and Research (IJBR), Vol. 5. pp 671-679.

Majumdar, S., Sarkar, M., Chowdhury, T., Chattopadhyay, B. and Mandal, S. (2012). Use of bacterial protein powder in commercial fly ash pozzolana cements for high performance construction materials. Open Journal of Civil Engineering, 2, pp. 218-228.

Mayur, S.V. and Jayeshkumar, P. (2013). Bacterial Concrete: New Era for Construction Industry. International Journal of Engineering Trends and Technology (IJETT).Vol 4, Issue 9, pp. 4128-4137.

MiyokoYanagi and KazuhideYamasato. (1993). Phylogenetic analysis of the family Rhizobiaceace and related bacteria by sequencing of 16S rDNA gene using PCR and DNA sequences. Federation of European Microbiological Societies 0378-1097/93/s06.00.

Parmar, A., Ankit, P. and Priyank, S. (2013). Improvement of the concrete cracks by using Bacillus Sphaericus. International Journal of Engineering Development and Research. ISSN: 2321-9939.

Quiviger, A., Payan, C., Chaix, J. F., Garnier, V., Salin, J. (2012). Effect of the presence and size of a real macro-cracl on diffuse ultrasound in concrete. NDT \& E International, 45, pp 128-132.

Ramachandran, S. K., Ramakrishnan, V. and Bang, S.S. (2001). Remediation of Concrete Using Micro-Organisms. American Concrete Institute: Materials Journal.

Ramakrishnan, V., Ramesh, K. P., and Bang, S. S. (2005). Improvement of concrete durability by bacterial mineral precipitation. South Dakota School of Mines and Technology, Rapid city, USA.

Talaro.K.P. and Chess.B. (2012). Foundations in Microbiology. $8^{\text {th }}$ Edition. Mc.Graw Hill. Pg 254-258.

Tittelboom, K. V., De Belie. N., Frank, L. and Christian, U.G. (2012). Acoustic emission analysis for the quantification of autonomous crack healing in concrete. Construction and Building Materials, 28, pp 333-341.

Varenyam, A., Abhijet, M. and Reddy, M. S. (2013). Biogenic treatment improves the durability and remediates the cracks of concrete structures. Construction and Building Materials, 48. pp. 1-5.

Wang, J., Tittelboom, K.V., De Belie, N and Verstraete, W. (2012). Use of Silica gel or polyurethane immobilized bacteria for self healing concrete. Construction and Building Materials, 26, pp 532-540.

Wiktor, V. andJonkers, H. M. (2011). Quantification of crack healing in Novel bacteria-based self healing concrete. Cement and Concrete Composites,33. pp. 763-770.

Wiktor, V., Sangadji, S., Jonkers, H. M., and Erik, S. (2013). Potential of Bacteria-Based Repair Solution as Healing Agent For Porous Network Concrete. ICSHM, pp 592-596.

Zhong, W. and Yao, W. (2018). Influence of Damage Degree On The Self-healing Of Concrete. Construction Building Material. 22, pp. 1137-1142. 